\title{
A Journey of Self-realization-An Interpretation of My Antonia With the Perspective of Jung's Archetype Theory
}

\author{
Ruilin Yang \\ School of English Studies, Xi' an International Studies University, Xi'an, 710000, China \\ Email:1551891316@qq.com
}

\begin{abstract}
As one of the classic "Nebraska Prairie" series novels, My Antonia can be regarded as a song of women's growth, praising women's persevering, pioneering and aggressive spirit. The author, Willa Cather, in the story portrays Antonia, a female character who insists on resisting the male authority of the patriarchal society and seeking self-identity. In the process of searching for her identity, Antonia grows from innocence to maturity, walking out of confusion and finding her own place. Through careful reading, it is not difficult to find that the process of Antonia's search for herself is actually a process of her inner world's continuous exploration and change, as well as constant adjustment and improvement of her thoughts. This psychological change process is actually suitable for further interpretation with the help of Jung's archetype theory, which is rarely used to interpret this work. From the perspective of archetype theory, Antonia's blind obedience to male power in the early period is due to her persona occupying a dominant position in her psychic structure, and later the awakening of animus in her subconsciousness promotes the development of masculinity in her character. She becomes independent and brave and shoulders the responsibility of her family. And finally, overcoming the obstacles of life and realizing her own value are the performances of Antonia's successful individuation. Therefore, this paper will mainly interpret Antonia's mental growth from three aspects of her persona, animus and successful individuation, as well as revealing the necessity and significance for individuals of appropriately adjusting various psychic factors and making them in a harmonious and balanced state.
\end{abstract}

Keywords: My Antonia, Jung's Archetype Theory, Persona, Animus, Individuation

\section{Willa Cather and My Antonia}

As an eminent American female writer in the first half of the $20^{\text {th }}$ century, Willa Cather with affectionate words and beautiful lyric techniques depicted the tenacious entrepreneurial spirit, perseverance and fortitude of the pioneers of the Midwestern United States in the late $19^{\text {th }}$ century from various perspectives, praising their noble sentiments and beautiful hearts. Willa in the nine moved to Nebraska with her parents, where immigrants from all over the world with different races, traditional customs, languages, cultures and religious beliefs were struggling to create a new history, germinating vitality throughout the grassland, nurturing the future, and sprinkling tears, sweat and even blood for the prosperity of today's America. Among these European immigrants from an early age, Willa learned about their homesickness and longing for the future, as well as their deep affection and attachment to the land; witnessed their bravery in the midst of hardship and fearlessness when fighting with nature, and also saw changes of the relationship among people and impacts on traditional morality and spiritual civilization caused by the accumulation of material. All of these left a deep and unforgettable impression on her, providing a rich source for her future literary creation.

The pioneering women portrayed in Willa Cather's works leave an indelible artistic image in the history of American literature. Being not satisfied with the traditional social destiny for women, Cather in her works breaks the universal definition of women in society and portrays the images of women pursuing independence, having the mind and ability to lead the family to success and even surpassing the man to bear the burden of family. The protagonist Antonia in one of her oeuvre My Antonia vividly describes the image of such female pioneer, and perfectly illustrates the characteristics of female images that break through the traditional in Cather's works: decisiveness, self-reliance, kindness and eagerness for family. ${ }^{[1]}$ These independent women, relying on their own abilities, make full use of the harmony between man and nature to create a sky of their own. In My Antonia, the protagonist Antonia and her family left the Czech Republic for the United States to start a new life. Here the land was barren and life was difficult. After her father's death, Antonia had to carry the burden of her family; after undergoing deception and abandonment by man, she still maintained her passion for life and expectations for the future. In the process of searching for self-identity, she 
gradually broke free from innocence and confusion, and walked to the maturity and self-realization. With the deepening of reading, it can be found that the protagonist Antonia is quite valuable to be studied. A large number of detailed descriptions in the novel show that Antonia's self-realization is accompanied by the difficult process of trade-off and struggle between the traditional female image she has shown and the real desire in her heart, and constantly adjustment of various psychic factors. This is a journey from succumbing to the power of the patriarchal society to realizing the struggle for freedom, and finally to the self-realization. This is the process of Antonia's self-transformation, and also the process of her continuous integration and improvement of various psychic factors at different stages. And this psychological change process actually can be clearly displayed and interpreted by part of Jung's archetype theory.

Archetype theory is an important part of Jung's extensive and profound research achievements, which taking collective unconsciousness and archetype as the core content, and focusing on exploring the permanent and universal human deep personality structure under the inescapable historical destiny. According to Jung's point of view, a person's process of finding inner self-completeness is self-realization, also called individuation. Through this process, he or she becomes a whole - the "real self". ${ }^{[2]}$ In Jung's view, a person's life-long task is the self-realization to achieve mental health and inner balance. In this process, people will face the following archetypes such as persona, shadow, anima or animus, and self, etc, which almost determine people's attitude towards the world and the way they deal with things. ${ }^{[3]}$ In My Antonia, Jung's archetype theory is reflected in Antonia's early traditional female image of being obedient to the patriarchal society, the awakening of self-awareness and breaking the shackles in the mid-term, and finally the success in overcoming the challenges of life and realizing the self value. From the perspective of Jung's theory, these can be regarded as Antonia's persona, animus and her successful individuation. Therefore, this paper will combine the story with the archetype theory to specifically discuss the reflection of persona, animus and individuation on Antonia from three facets: (1) External restraint---Antonia's persona; (2) Inner awakening---Antonia's animus; (3) Self-realization---Antonia's individuation. After experiencing many choices in life, Antonia has achieved the most complete psychological growth, namely self-realization. In this process, with self-awareness being awakened she is brave to break the constriction of her persona and traditional shackles of women, and dares to challenge the male authority, so that her animus can be released properly instead of being overly suppressed. And finally, through the integration of psychic factors and personal unremitting efforts she achieves the harmony and balance among her own archetypes, achieving the successful individuation, opening up the business, and realizing her own value. It can be said that under the social conditions at the time, Antonia's efforts and attempts are hard but noble.

\section{External Restraint---Antonia's Persona}

Persona is a kind of functional complex existing in order to adapt to the environment or personal interests. It is a product of the compromise between the needs of the environment and the needs of the self. As Jung said that persona is a compromise between the individual and society about what a person should be. All of these are the realities in a sense, but relative to the person's basic personalization, it is nothing more than a secondary reality and a product of compromise. In forming such persona, other people often enjoy a larger share than him or her self. ${ }^{[4]}$ It can be seen that the environment the individual is in has a greatly direct impact on the formation and characteristics of his or her persona. In the context of the novel, people's understanding of family and the roles of men and women were still quite traditional. In the family, men were the decision makers, rulers and leaders, and women should only obey and accept. For example, when Jim in the childhood talked about Antonia, he thought that even if Antonia was four years older than himself and had seen more of the world, but because Antonia was a girl, and he was a boy, Jim resented her such protecting manner. Later, when Antonia began to obey his arrangement, he then thought that "she began to treat me more like an equal". ${ }^{5]}$ Similarly, Antonia's brother also thought that "every cent of his sister's wages should be paid over to him each month, and he would provide her with such clothing as he thought necessary". ${ }^{[5]}$ From these male perspectives, it is clear that how the society treated women at that time. As a woman living in a patriarchal society and being influenced for a long time, Antonia, like many other women, thought that all should be like this in her heart, and she should silently accept all of her brother's arrangements. Although his brother was rude, Antonia never opposed him, and her obedience and respect for his brother were still intact. This is the surrender of power generally accepted by the public under the patriarchal society. At the beginning, Antonia also accepted this concept, because only in this way could she be easily accepted by society and others without conflict. It is for this reason that Antonia had such a panic "if I lose that horse...I never stay here still Ambrosch come home! I go drown myself in the pond before morning", ${ }^{[5]}$ and described Jim's "heroic" behavior in killing snakes with admiration. These are all manifestations of women's humble status under the patriarchal system. It can be seen from these that in the early stage Antonia's thoughts were deeply influenced by the social dogma at that time. In The Archetype and the Collective Unconsciousness, Jung explained the influence of dogma on the unconsciousness of people as following: Dogma takes the place of the collective unconscious by formulating its contents on a grand scale...Almost the entire life of the collective unconscious has been channeled into the dogmatic archetypal ideas and flows along like a well-controlled stream in the symbolism of creed and ritual. ${ }^{[2]}$ It can be seen that at the unconscious level, Antonia is deeply influenced by the background of the time and social dogma. Although we can see from some of the early details that 
Antonia did not agree with such a female status, like she "had opinions about everything, and she was soon able to make them known", ${ }^{[5]}$ she still chose to obey men's arrangements like many women, and acknowledged her subordinate and humble social status. She played such a female image to achieve the purpose of being accepted by society and others. According to Jung's archetype theory, this is the embodiment of her persona.

Many people mistakenly believe that persona is purely deceptive and does not meet human desires, but actually persona is necessary for a person to adapt to the world, and therefore is also necessary for proper psychological function. ${ }^{[4]}$ If a person does not have a well-developed persona, this person may not be able to gain a good foothold in society, and it is impossible to achieve the goals that can only be achieved by relying on him to make a positive impression for others. But persona also has some obviously negative aspects. According to Ja-cobi, the student of Jung, "the persona is characterized by superficiality, boredom, rigidity and mediocrity". ${ }^{[4]}$ For example, in Arthur Miller's book Death of a Salesman, the persona recognized by the protagonist Willie Lohman is "a smile and red face". When he stops being a salesperson, due to the emptiness he feels and being unable to bear such feeling, he ends his life with suicide.

Persona is largely autonomous, and may play its role regardless of the desires of the self. This role is played on the points that conflicts with the desires of the self. Therefore, if a person's ego is very fragile, his persona will then replace it. We can call this situation "identity of ego and persona". ${ }^{4]}$ However, in this novel, Antonia was not satisfied with such state of existence, nor was she excessively immersed in such a persona, which will incur some tragic consequences according to Jung. ${ }^{[6]}$ On the contrary, she chose a difficult struggle, which started from her efforts to fighting for the right to dance. When $\mathrm{Mr}$. Harling asked her to choose between giving up dancing and leaving, she insisted on safeguarding her dancing right and decided to leave. To some extent, this is the first step of her self-awakening and the beginning of her attempt to separate herself from her persona. For her, dancing is not merely a recreational activity, but a symbol of right and dignity. She begins to jump out of the shackle of her persona and objectively examine the relationship between her persona and her consciousness and subconsciousness. She does not deliberately carry out such an examination, but her actions and thoughts have reflected that she begins to have such thinking subconsciously. When Mrs. Harling was stunned that the usually obedient Antonia made such a choice and asked her what happened, Antonia replies: "I don't know...A girl like me has got to take her good times when she can...I guess I want to have my fling, like the other girls." "[5] This shows that although Antonia did not yet have a completely independent self-consciousness, but she had realized that as an independent individual, she had the right to pursue happiness and freedom. She began to overcome the negative impact that the persona of humble female images had on her, and this is the necessary prerequisite for her animus to fully develop later and of achieving the successful individuation.

\section{Inner Awakening---Antonia's Animus}

It is a well-known fact that sex is determined by a majority of male or female genes. But the minority of genes belonging to the other sex does not simply disappear. A man therefore has in him a generally unaware feminine side, which is called the "anima", and its counterpart in a woman the "animus". ${ }^{2]}$ According to Jung's view, if animus develops moderately and is properly controlled, it will bring a positive impact, and the masculine traits it reflects will become the "priceless inner friend" of the female personality, giving her aggressiveness, courage, objectivity and extraordinary wisdom. ${ }^{[4]}$ At the same time, it also provides her with spiritual beliefs, giving her a hidden inner support to supplement her external weakness. Antonia is just a female figure whose animus develops moderately and has a proper amount of masculinity, which thus harmoniously complementing her persona.

At the beginning, Antonia did not show her independent and decisive style of dealing, but chose to obey male power, which was partly due to her father's early influence on her. According to Jung's view, women's animus mostly comes from their father, the male whom they earliest get along with, which affects women's way of doing things and behavioral characteristics in the future. In the novel, Antonia's father knows "how to make the fine cloth...He plays horn and violin, and he read so many book", ${ }^{[5]}$ but in the eyes of people at that time, he did not have the masculinity admired in traditional ideas. Due to Antonia's father's weak personality, under his influence Antonia's animus failed to fully develop in the early days, and the independent aspect of her masculinity was not reflected. Because of the incomplete development of animus, her persona prevailed in her psychic structure in the early days, and she chose to obey the patriarch. The second reason why she chose to submit to the male power is that she did not encounter the corresponding situation that inspired her animus. Jung believes that since everyone has certain characteristics of the opposite sex, in order to achieve a harmonious balance of personality, it is necessary to allow the anima archetype in male personality and the animus archetype in female personality in human conscious behavior to develop in a balanced way. But archetype just exists in the subconsciousness, which is hollow and abstract. Only when it is combined with a specific situation can it be stimulated and surfaced. ${ }^{[4]}$ In the story, when Antonia's father died, Antonia must help Ambrosch share the farm work and began to take care of and support the family, which actually can be seen as the situation that inspires her animus. After her father's death, Jim ever asked Antonia why she could not be like she used to, but always wanted to make herself like Ambrosch. Antonia replied that "if I live here, like you, that is different. Things will be easy for you. But they will be hard for us". ${ }^{[5]}$ This shows that after the death of her father, the hardship of life had a great impact on Antonia, and even Jim felt that "she was now grown up and had no time for me". ${ }^{[5]}$ In such an environment, Antonia needed to become independent and work like a man. Because of this, her animus which was unable to fully develop due to her father's influence and 
the lack of proper situational stimulation grew up quickly, greatly affecting her subsequent behavior and choices.

According to Jung's theory, if one wants to realize his or her individuation and become a mature individual, it is very necessary to fully develop and express his or her anima or animus. After having to bear the responsibility of taking care of the family, Antonia experienced emotional discomfort again that her fiancé abandoned her, and later her husband also had little knowledge of farm work, so Antonia had to take up most of the work...After all these, Antonia had never complained, been pessimistic or desperate but always strong and optimistic, constantly adjusting herself to adapt to various environments. After her father died, she chose to work like a man, determined to help turn this land into a good farm; after her frustrating emotional experience and being abandoned by her fiancé, she did not complain or care about common custom, but took good care of the children alone; when life was difficult and her husband knew little about farming, Antonia relied on her own strength to take the responsibility of supporting the family and arranged everything well...All these situations made Antonia's animus that had not been completely expressed fully stimulated, and allowed her subconsciously male traits such as independence, strength and courage to have the opportunity to be displayed. Without the reasonable compensation and correct support of masculinity of her animus, a weak woman as Antonia in such difficult environment definitely can not do these. Accompanying her continuous maturity and perfection is the awakening of her ego. After fully expressing her animus, Antonia gradually recognized her heart and knew the goal and life she pursued, paving the way for her later successful process of individuation.

\section{Self-Realization---Antonia's Individuation}

When Jim saw Antonia again many years later, she was no longer young and had become the mother of eleven or twelve lovely children. At this time, she was a kind mother who took care of the family and children, and was also a friend who could face difficulties and solve them with her husband. She felt life from the experience of suffering and rediscovered the center of life. At this time Antonia was devoting her energy to creating a harmonious family atmosphere, and as a woman everything she did showed her female and maternal emotions. In a certain sense, she played the spiritual backbone of the people around her, and even Jim, who had reunited with Antonia after many years, said to her as following: "you influence my likes and dislikes, all my tastes, hundreds of times when I don't realize it. You really are apart of me". ${ }^{[5]}$ After experiencing the good and bad, happiness and frustration of life, Antonia did not make herself one of thousands of women who succumbed to patriarchy due to the constraints of society and the times, and did not lose her passion for life due to the hardships. She was optimistic and hard-working, took care of the family and children well, and lived the life she wanted by her own efforts. In the process, she realized her value and found herself. Jung once discussed the importance of why people should recognize themselves and find themselves: "There I am utterly one with the world, so much a part of it that I forget all too easily who I really am. "Lost in oneself" is a good way of describing this state. But this self is the world, if only a consciousness could see it. That is why we must know who we are". ${ }^{[2]}$

Actually the process of recognizing and finding oneself actually reflects the process of achieving individuation to a certain extent. The term "individuation" denotes the process by which a person becomes a psychological "in-dividual", that is, a separate, indivisible unity or whole. ${ }^{[2]}$ When the individual has a clear and correct understanding of the question of who I am, he or she inevitably needs to integrate the psychic factors to make them in a balanced and harmonious state and become an inseparable whole, so that the self will not be hindered by any psychic factors that are over-developed or incompletely developed, and this is the process of individuation. According to Jung's definition, individuation leads to the unification, integrity and inseparability of personality through the integration of conscious and unconscious parts. Specifically speaking, individuation strengthens, differentiates and integrates various non-self aspects of the spirit (including shadow, persona, non-dominant attitudes and function types, anima and animus, etc.), and makes them a psychologically indivisible whole. In the novel, Antonia's persona occupied a large proportion of her early psychic structure, to a certain extent dominating her behaviors and thoughts and guiding her to obey the patriarchy and submit to men. Later, because of the pressure of life, she had to shoulder the responsibility of taking care of the family and face the setbacks and challenges of life alone, allowing her animus that lacked in her early development to fully develop. In this process, she did not overly immerse herself in her persona but allowed her various psychic factors to have the opportunity to develop, thus providing conditions for these psychic factors to form an indivisible whole. And this lies as the main reason for her successful process of individuation.

Individuation is related to the crisis in life, mainly a challenge encountered in middle age. If being recognized, individuation may accelerate its development and promote rapid internal growth and conversion. This is a dynamic life process, during which arduous self-exploitation and search for internal sources will occur. It is a creative introversion stage of libido. At this stage, the previously preserved subconsciousness seems to "push" or "force" more self-realization as part of the natural tendency of the spirit to achieve overall integration. ${ }^{[4]}$ According to Jung, in the childhood, the ego and the self which are the core of consciousness are only weakly related to each other. As the age increases, after middle age (35-40 years old) the ego through life experience will then deepen and establish a strong and lasting relationship with the self. When people reach the initial goals of society, marriage and family life, they will inevitably seek further meaning of existence. Many people can not extricate themselves because they 
can not find the meaning of life, resulting in spiritual emptiness, decadence, and even falling into neurosis. ${ }^{[4]}$ Jung believes that the task faced by middle-aged people is how to complete the transition from external adaptation to internal adaptation to make their psychological activities can be turned to their inner world and self-realization. At this time, a strong ego is needed. If the ego is very weak, it will be overwhelmed by the content of various archetypes, making it schizophrenic and people get mental illness or neurosis. However, when the ego is strong, the subconscious content will continue to assimilate with the ego, and the ego will then become stronger. In the novel, when Jim and Antonia met again many years later, Antonia was already a middle-aged woman, and at this time she had already married and had children. In her middle age, after the initial goals of society, marriage and family life had been reached, Antonia was now in a stage of transition from external adaptation to inner world and self-realization. If wanting to successfully pass this stage, according to Jung's view, a strong ego is particularly important. Fortunately, after going through a series of life twists and turns, Antonia's ego had grown strong and independent enough not to lose herself in the face of various archetypes. After the reunion, Jim had such a feeling: I know so many women who have kept all the things that she has lost, but whose inner glow has faded. Whatever else was gone, Antonia had not lost the fire of life. Her skin, so brown and hardened, had not that look of flabbiness, as if the sap beneath it had been secretly drawn away. ${ }^{[5]}$ The fire of her life can be said to be her ego. Unlike those women who bowed their heads to destiny, succumbed to male power, and gave up their desires for life and finally lost themselves in the long years, Antonia "...was there, in the full vigour of her personality, battered but not diminished". ${ }^{[5]}$ Instead of being influenced by different archetypes on herself, she actively integrated various psychic factors in subconsciousness. At this time, she retained part of the persona that taking care of the family and her children. She was a qualified mother and wife, a "natural-born mother", ${ }^{5]}$ which was in line with the society's recognition and demanding of women. At the same time she actively developed her own animus. She would wear a long coat and boots and a broad-brimmed hat worn by a man, and would continuously work without feeling tired. She loved working, and loved every tree and every grain of food she planted, treating them as if they were humans, which fully embodies her differences from traditional women. On the basis of balanced and harmonious development of these archetypes, her successful individuation is a normal thing. She successfully integrated various non-self aspects of the spirit and made them become a psychologically inseparable whole. Such individuation is successful, and Antonia with such individuation is described by Jim as "a new kind of strength in the gravity of her face". ${ }^{[5]}$ Despite her old age, she still "had that something which fires the imagination, could still stop one's breath for a moment by a look or gesture that somehow revealed the meaning in common things". ${ }^{[5]}$

\section{Conclusion}

This paper mainly analyzes the realization process of Antonia's self value in My Antonia from the perspective of psychology by Jung's archetype theory. Since its publication, most people's analyses of this work have started from the aspects of eco-feminism and narrative skills, but few has analyzed from the perspective of Jung's archetype theory. With the help of this theory, we can clearly see the maturing process of Antonia's psyche. Earlier, due to the influence of social environment, she had the persona being obedient to patriarchy. At this time, her ego was dependent on men, namely her father and brother. Then the family's change and the hardships of life inspired Antonia's animus which was unable to be fully expressed due to her father's influence and the lack of a specifically stimulating situation, giving expression to the male qualities like bravery and courage of her character, providing her with the motivation to support her shouldering the responsibility of taking care of and raising her family, and letting her face the hardships of life and try to overcome them. Finally in the middle age, with her strong self-support she balanced her archetypes of persona and animus. And after integrating them reasonably into an inseparable whole, her individuation finally succeeded, creating a happy atmosphere for the family, changing the old world with practice, and establishing a new home.

By successfully portraying the image of Antonia, Cather shows readers a new woman with self-awareness and right-consciousness, just as what mentioned in the end that Antonia had always been one to leave images in the mind that did not faded---that grew stronger with time. ${ }^{[5]}$ When the work embodies the necessity of breaking the various restrictions of patriarchy on women, showing that women can make the same achievements and bear the same responsibilities as men, from a psychological perspective, it at the same time reflects the significance and necessity for individuals of balancing and integrating various archetypes to put them in a harmonious status. Only in this way can the individual be in a state of sobriety and reason, can he further understand himself, and thus have the opportunity to realize his own value and meaning.

\section{REFERENCES}

[1] Fu, X.X. (2014) An Analysis of the Female Images in Willa Cather's Works. New West, No.12: 98+94.

[2] Jung, C.G. (1968) The Archetype and the Collective Unconscious. Princeton NJ: Princeton University Press, Princeton.

[ 3 ] Wang, Y.N. (2019) Isabel's Self-realization: Interpretation on "The Portrait of a Lady" in the Light of Jung's Archetypal Theory. The Science Education Article Collects, No.01: 161-162. 
[4] Yang, S.G. (2017) Mysterious Carl Jung. Jiangxi

People's Publishing House, Jiangxi.

[5] Cather, W. (1996) My Antonia. Modern Library, New

\section{York.}

[6] Shan, L.X. (2014) A Analysis of the Psychic Structure of the Governess. Inheritance \& Innovation, No.05: 138-139. 